\title{
Development of Mathematics Mobile Learning Application Through Discovery Learning Method
}

\author{
D Pamungkas ${ }^{1}, \mathrm{~N}_{\text {Aini }}{ }^{2}, \mathrm{~S}_{\text {Pitriyana }}{ }^{3}$, and D Sulisworo ${ }^{4}$ \\ \{dwi.pamungkas1@gmail.com ${ }^{1}$, noorainimath@gmail.com², \\ sisi1708050023@webmail.uad.ac.id ${ }^{3}$ \} \\ Universitas Ahmad Dahlan, Pandeyan, Yogyakarta, Indonesia ${ }^{1,3,4}$, Universitas Pendidikan \\ Muhammadiyah Sorong, West Papua, Indonesia ${ }^{2}$
}

\begin{abstract}
This study aims to produce learning media for Mobile Learning for class VII students of SMP/MTs through the Discovery Learning method and test the feasibility of applications in mathematics learning. This research is a development research with steps 4-D Research and Development (R \& D) model (Define, Design, Develop, Disseminate). The study was conducted at SMP Muhammadiyah 1 Kalasan, Sleman Regency. This research data is obtained from student response evaluation sheets by students. Research data were analyzed by descriptive analysis process and questionnaire analysis process with Likert scale. The results showed that the Mobile Learning Mathematics application developed was of good quality. Thus, the application of Mobile Learning mathematics material is set for students of class VII SMP/MTs through Discovery Learning methods that are feasible to be used in mathematics learning.
\end{abstract}

Keywords: Learning, Media, Mobile, Application

\section{Introduction}

Law Number 20 of 2003 concerning the National Education System explains that learning activities are the process of interacting students with educators and learning resources in a learning environment that aims to develop the potential of learners so that they become faithful and fearful people of God Almighty. noble, healthy, knowledgeable, capable, creative, independent, and democratic and responsible citizen. Based on educational goals, it appears that student learning is not just about teaching knowledge. The law has laid strong foundations in supporting the development of national character and identity.

National education aims to develop abilities, one of the abilities developed is the ability to think creatively. Creative thinking is classified as high-level competency (high order competencies) and can be seen as a continuation of basic skills. Creativity plays an important role in the cycle of advanced mathematical thinking [1]. Furthermore, according to the Maine Career Center Department of Labor USA, the ability to think creatively is important because this ability is one of the abilities desired by the workforce [2]. These statements indicate that the ability to think creatively is an important ability to be improved.

One of the successes of student learning is determined by the teacher as an educator. The use of varied learning models can support student learning success. This is in line with the opinion which states, the application of innovative and constructive learning models is more 
appropriate in developing and exploring student's knowledge in a concrete and independent manner [3]. There are so many learning models that can be applied by the teacher in the learning process so that students can absorb the material and improve thinking skills.

The performance and competencies of the teacher bear the main responsibility in changing student orientation from ignorance to knowledge, from dependence to being independent, from being unskilled to skilled, to learning methods no longer preparing passive students, but knowledgeable students who are always able to absorb and adjust yourself with new information by thinking, asking, exploring, creating, and developing certain ways to solve problems related to their lives [4].

One model that teachers can apply is cooperative learning which is a learning model that emphasizes the process of cooperation in a group [5]. Cooperative learning is designed so that every individual involved in learning works together and interdependently with each other in a task structure and purpose [6]. In cooperative learning, students are directed to cooperate and help to help in groups to understand the material of a lesson so as to grow a high social sense among fellow members in the group [7]. The cooperative learning model is carried out by dividing students into small groups in learning the material being studied the division of the group was made heterogeneous, both in terms of learning achievement and gender [8] [9]. This cooperative skill serves to facilitate work relationships and tasks [10]. Cooperative learning model one of which is discovery learning.

Discovery learning is a learning theory that is defined as a learning process that occurs when students are not presented with lessons in their final form but are expected to organize themselves [11]. Discovery learning foster student creativity in learning [12]. The purpose of discovery learning model, which is to give students the opportunity to be actively involved in learning, encourage students to learn actively by connecting the experiences of students with new experiences learned so that students can find answers to the problems given by the teacher [13].

Discovery learning models are considered able to boost student's mathematical problemsolving abilities in mathematics learning [14]. This model is effective in encouraging student involvement and motivation while helping them gain an in-depth understanding of clear topics [15]. Discovery occurs when individuals are involved, especially in using their mental processes to find several concepts and principles, through observation, classification, measurement, prediction, determination, and inferiority. Therefore, with the discovery learning model, students will be able to store knowledge longer in their memory because they find their own answers [16].

In discovery learning requires students to find new things, the process of discovering new things requires creativity, so that the discovery learning model and the syntax in it can improve student's creative thinking. This is in line with the results of Schlenker's research which shows that the practice of inquiry can improve understanding of science, productive in creative thinking, and students become skilled in obtaining and analyzing information [3].

To overcome this problem, learning media is needed in order to produce maximum learning outcomes. One of them is the media using the eXe learning application. eXe eLearning is a writing program, where teachers can develop and publish learning material without the need for expertise in programming languages [17]. The material can be presented in the form of tutorials and accompanied by multiple choice practice questions. The eXe learning program is an acronym for eLearning XHTML editor, a program used to make Webbased teaching materials designed to convey learning materials easier and more interesting [18]. 
In eXe learning programs, teachers can create Web-based teaching materials without needing to know about HTML, even easier than Web editors like Ms. Frontpage. In the eXe learning program, the teacher only opens the eXe learning page, then fills with text, images, videos and then automatically forms a table of contents that links to all pages [19]. But in these studies, the mathematical concepts associated with Discovery Learning have not been applied in eXe learning media development.

Mobile Learning is the next generation of e-Learning and is based on mobile devices [20]. In cellular learning, two main concepts are cellular people and students. Smart learners are supported by their willingness to cellular learning and objects [21]. Cellular learning is a relatively new phenomenon and its theoretical foundation is under development [22]. Cellular learning refers to the use of cellular devices in the learning process considering two mobility attributes and wireless connections anywhere on the right path [23].

Mobile learning is defined as the use of portable computers or interactive electronic devices and constantly communicating in collaborative learning sessions field work, guidance or counseling and the process is more specific to experience specific domains and support application innovation in learning [24]. Mobile Learning has received a lot of critical, theoretical and empirical research attention in recent years. More and more sophisticated mobile devices and their potential for use in education are described as 'new paradigms' [25].

By utilizing technological developments at this time, researchers try to develop a Mobile Learning mathematics learning media set material through Discovery Learning methods that are designed as attractive as possible. In supporting the development of the Mobile Learning mathematics learning media, researchers used an open source application that is in accordance with the e-learning standard, eXe (learning XHTML editor).

\section{Methods}

Research on the development of Mobile Learning applications is in accordance with the steps contained in Research and Development (R \& D) developed by Sugiyono by adapting the 4-D development model through 4 (four) stages, namely Define, Design, development (Develop), and spread (Disseminate) [26]. The subjects in this research and development consisted of seventh-grade students of SMP Muhammadiyah 1 Kalasan, Sleman Regency. This development research uses data collection techniques, namely literature study and questionnaire. Research data was obtained using data collection instruments, namely student response test instruments. From the data that has been collected, the average can be calculated using the equation (1) [27].

$$
\bar{X}=\frac{\sum_{i=0}^{n} X_{i}}{N}
$$

Information :

$$
\begin{array}{ll}
\bar{X} & : \text { Average score } \\
\sum_{i=0}^{n} X_{i} & : \text { Total score } \\
\mathrm{N} & : \text { Number of assessors }
\end{array}
$$

Furthermore, the data obtained from class VII students are converted into qualitative values based on the ideal assessment criteria. The provisions of the ideal assessment criteria are shown in Table 1. 
Table 1. Ideal Assessment Category Criteria.

\begin{tabular}{lll}
\cline { 2 - 2 } No. & Score Range $(i)$ Quantitative & Qualitative Category \\
\hline 1. & $\bar{X}>\overline{M_{i}}+1,8 S B_{i}$ & Very good \\
2. & $\overline{M_{i}}+0,6 S B_{i}<\bar{X} \leq \overline{M_{i}}+1,8 S B_{i}$ & Good \\
3. & $\overline{M_{i}}-0,6 S B_{i}<\bar{X} \leq \overline{M_{i}}+0,6 S B_{i}$ & Enough \\
4. & $\overline{M_{i}}-1,8 S B_{i}<\bar{X} \leq \overline{M_{i}}-0,6 S B_{i}$ & Less \\
5. & $\bar{X} \leq \overline{M_{i}}+1,8 S B_{i}$ & Very less \\
\hline
\end{tabular}

\section{Result and Discussion}

At define stage reference studies were carried out from various sources, discussions with lecturers about the potential and problems in developing Mobile Learning. At this stage, reference studies were carried out from various sources, both from the internet and print media regarding the information used in developing Mobile Learning.

Then in the design stage, curriculum analysis is carried out by looking at the subject matter and learning experience of the material set, then the competencies that must be possessed by students, compile a map of Mobile Learning needs which is a diagram of writing Mobile Learning material and to determine the amount of material to be written, and determine learning activities in Mobile Learning that have been developed, using Discovery Learning methods.

Mobile Learning applications that are developed have characteristics, including the contents of Mobile Learning are adjusted to core competencies and basic competencies that are developed based on the curriculum 2013, using simple language, and Mobile Learning uses pictures and illustrations that are in accordance with the material. Some menu functions in the Mathematics Mobile Learning application, including (1) Understanding, so that students understand the meaning or meaning contained in the understanding of the set, (2) Notation, allows students to look at symbols or symbols that describe a set, (3) Declare a set, so that students are able to understand three ways of expressing a set, (4) Set of numbers, so that students are able to explain the number of types of numbers, (5) Types, making it easier for students to understand the many kinds of sets, (6) The subsets, making it easy for students to understand a set that is contained in another set, (7) Set Questions, contains daily life problems with Discovery Learning methods, (8) Postest questions, training student's understanding of the set material that contains 10 Multiple Choice questions.

Mobile Learning applications that have been created are then tested to 16 students of class VII SMP Muhammadiyah 1 Kalasan, Sleman Regency which are randomly selected. The products that have been made are promoted online which can be downloaded via the following link. https://drive.google.com/open?id=1nc_4vtRSq4CDEIVjMHIRyW48MV74Me_4

Student's responses to the developed Mobile Learning Mathematics application are known based on the results of questionnaires given and filled out by students during the trial. The results of the student response questionnaire calculation can be seen in Table 2 . 
Table 2. Student Response Questionnaire Results.

\begin{tabular}{clcccc}
\hline No. & $\begin{array}{c}\text { Criteria Item } \\
\text { Statement }\end{array}$ & $\begin{array}{c}\text { Ideal Maximum } \\
\text { Score }\end{array}$ & $\begin{array}{c}\text { Amount of Score } \\
\text { Obtained }\end{array}$ & $\begin{array}{c}\text { Average Amount of } \\
\text { Score Obtained }\end{array}$ & Percentage \\
\hline 1. & Usefulness & 32 & 429 & 26,81 & $83,79 \%$ \\
2. & Ease of Use & 44 & 589 & 36,81 & $83,66 \%$ \\
3. & Ease of Learning & 16 & 224 & 14,00 & $87,50 \%$ \\
4. & Satisfaction & 28 & 386 & 24,13 & $86,16 \%$ \\
\hline
\end{tabular}

Seen in the table above that the quality of the Mobile Learning mathematics application from the trial at the research location with details for usefulness criteria (obtained) obtained an average score of the questionnaire calculation results of 26,81 ; ease of use criteria (ease of use) obtained an average score of the results of the questionnaire calculation 36,81 ; ease of learning criteria (ease of learning) obtained by an average score of the results of questionnaire calculation 14,00; and the criteria of satisfaction (satisfaction) obtained an average score of the results of questionnaire calculations 24,13 . Acquisition of each student questionnaire response results are in the validity criteria shown as in Table 3.

Table 3. Criteria for Ideal Assessment Category of Student Response.

\begin{tabular}{lllllll}
\hline \multirow{2}{*}{ No } & \multicolumn{4}{c}{ Quantitative Score Range } & Qualitative \\
\cline { 2 - 5 } & Usefulness & Ease Of Use & Ease of Learning & Satisfaction & Total & Category \\
\hline 1 & $\bar{X}>27,2$ & $\bar{X}>37,4$ & $\bar{X}>13,6$ & $\bar{X}>23,8$ & $\bar{X}>102$ & Very good \\
2 & $22,4<\bar{X} \leq 27,2$ & $30,8<\bar{X} \leq 37,4$ & $11,2<\bar{X} \leq 13,6$ & $19,6<\bar{X} \leq 23,8$ & $84<\bar{X} \leq 102$ & Good \\
3 & $17,6<\bar{X} \leq 22,4$ & $27,5<\bar{X} \leq 30,8$ & $8,8<\bar{X} \leq 11,2$ & $15,4<\bar{X} \leq 19,6$ & $66<\bar{X} \leq 84$ & Enough \\
4 & $12,8<\bar{X} \leq 17,6$ & $17,6<\bar{X} \leq 27,5$ & $6,4<\bar{X} \leq 8,8$ & $11,2<\bar{X} \leq 15,4$ & $48<\bar{X} \leq 66$ & Less \\
5 & $\bar{X} \leq 12,8$ & $\bar{X} \leq 17,6$ & $\bar{X} \leq 6,4$ & $\bar{X} \leq 11,2$ & $\bar{X} \leq 48$ & Very less \\
\hline
\end{tabular}

From the table above, the Mobile Learning mathematics application developed for usefulness criteria and ease of use is in a good category, while for the criteria of ease of learning and satisfaction are in the excellent category.

From the experiments conducted can be obtained the calculation results of the average overall criteria for student response questionnaires of 101,75 . These results indicate that $84<$ $\bar{X} \leq 102$, so that the quality of the Mobile Learning mathematical application of set material for students of class VII SMP/MTs through the Discover Learning method developed is included in the criteria of good and feasible to be used in the learning process.

Mathematics learning media that has been tested on students, then distributed. Here are some descriptions of the results of the development of the Mobile Learning application of the mathematical set material. 


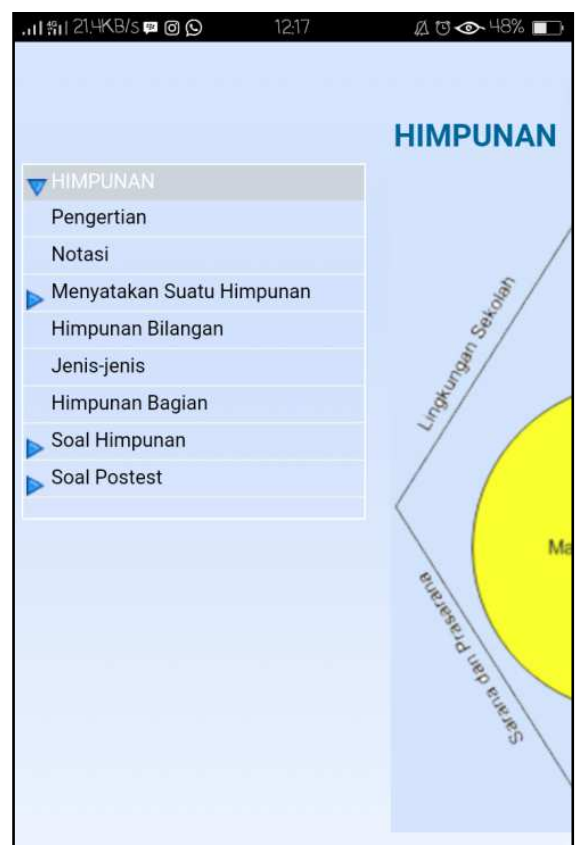

Figure 1. Display menu of the Mobile Learning mathematics application.

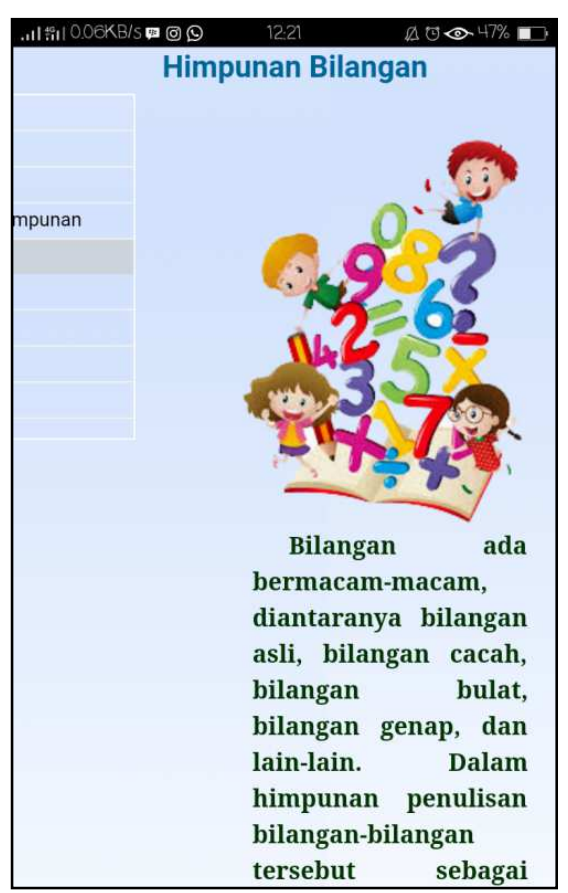

Figure 3. Display contents of the Mobile Learning mathematics application.

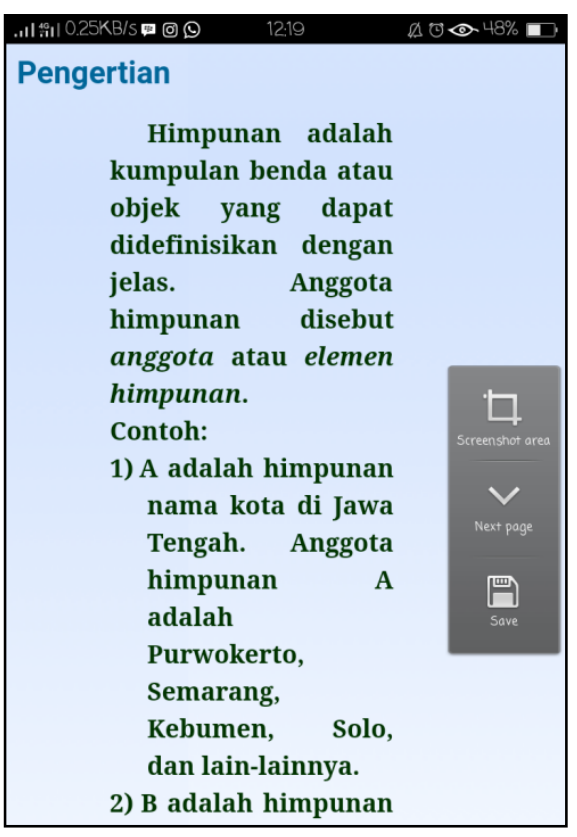

Figure 2. Display the contents of the Mobile Learning mathematics application.

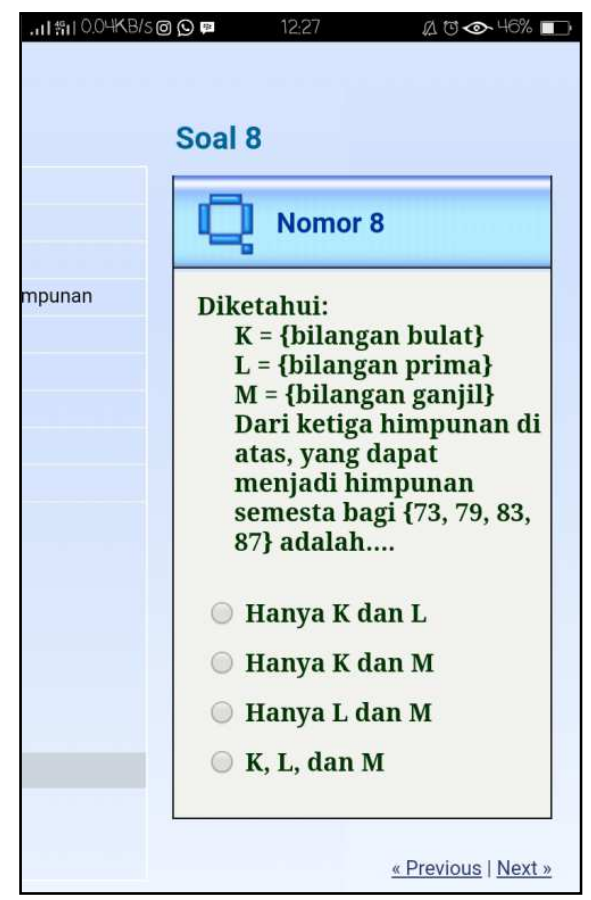

Figure 4. Display questions about the Mobile Learning mathematics application. 


\section{Conclusion}

After the Mobile Learning Mathematics application, the set material was developed, then a trial was conducted to find out the student's response to the Mobile Learning mathematics application through the Discovery Learning method developed. Based on these assessments, it can be concluded that in general the developed Mobile Learning mathematics application is included in the good category. Thus, the Mobile Learning mathematical application of set material for class VII students of SMP/MTs through Discovery Learning methods is appropriate to be used by teachers to teach and students to study independently at school or outside the school.

\section{References}

[1] Ervync G 1991 Mathematical Creativity (London: Kluwer Academic Publisher)

[2] Mahmudi 2010 Manajemen Keuangan Daerah (Jakarta: Erlangga)

[3] Triyanto 2009 Mendesain Model Pembelajaran Inovatif-Progresif:Konsep Landasan, Implementasi Pada Kurikulum Tingkat Satuan Pendidikan (KTSP) (Jakarta: Kencana)

[4] Ilyas, M I 2010 Kinerja dan Kompetensi Guru Dalam Pembelajaran LENTERA PENDIDIKAN 44-63

[5] Fauziah 2017 Penerapan model pembelajaran kooperatif tipe stad untuk meningkatkan ketuntasan belajar siswa pada pokok bahasan termokimia Jurnal Pendidikan Kimia 347-51

[6] Safitri D, Maryam and Mustami M K 2016 Pengaruh Strategi Pembelajaran Arias Setting Model Pembelajaran Kooperatif Tipe NHT Terhadap Motivasi dan Hasil Belajar Biologi Jurnal Biotek 181-91

[7] Abdullah R 2017 Pengaruh Penerapan Model Pembelajaran Kooperatif Lantanida Journal 1328

[8] Nismawati, Ismaimuza D and Idris M 2016 Perbedaan Hasil Belajar Matematika Antara Model Pembelajaran Kooperatif Tipe Student Teams Achievement Division (STAD) Dengan Two Stay Two Stray (TSTS) Berdasarkan Self-Efficacy Siswa SMP Negeri I Ampana Kota AKSIOMA Jurnal Pendidikan Matematika 445-56

[9] Rais H 2015 Comparison Of The Effectiveness Of Cooperative Model Of STAD Type and Problem-Based Learning Model With Scientific Approach On Sequence and Series Lesson Material In Class X IPA at SMAN 1 Duampanua JURNAL DAYA MATEMATIS 221-33

[10] Sudarma T F and Motlan 2013 Efek Model Pembelajaran Kooperatif Tipe STAD Berbasis Just-In Time Teaching Terhadap Hasil Belajar Fisika Pada Mata Kuliah Fisika Sekolah di Jurusan Fisika Fmipa UNIMED Jurnal Pendidikan Fisika 9-15

[11] Dwiastuti S, Suciati and Purnamasari D 2016 Pengaruh Penerapan Media Augmented Reality Berbasis Discovery Learning Terhadap Hasil Belajar Pada Materi Darah BIO-PEDAGOGI 7 14

[12] Sutama and Mayasri A 2016 Hasil Belajar Matematika Dengan Strategi Discovery Learning dan Group Investigation ditinjau Dari Keaktifan Siswa SMP Varia Pendidikan 1-10

[13] Furoidah A Z, Indrawati and Subiki 2017 Implementasi Model Discovery Learning Disertai Lembar Kerja Siswa Dalam Pembelajaran Fisika Siswa Di SMA Jurnal Pembelajaran Fisika 285-91

[14] Herdiana Y 2017 Perbandingan Pemecahan Masalah Matematis Siswa Antara Discovery Learning dan Problem Based Learning KALAMATIKA Jurnal Pendidikan Matematika 131-46

[15] Yulianti K, Mardiyana and Saputro D R 2014 Eksperimentasi Model Penemuan Terbimbing dan Model Pembelajaran Berbasis Masalah Pada Pokok Bahasan Trigonometri ditinjau dari Kreativitas Siswa SMA Se-Kota Salatiga Tahun Pelajaran 2013/2014 Jurnal Elektronik Pembelajaran Matematika 1106-18

[16] Patandung Y 2017 Pengaruh model discovery learning terhadap peningkatan motivasi belajar IPA Siswa Journal of Educational Science and Technology 9-17 
[17] Maria E, Pozzatti M L, Marli A and Rockenbach L M 2011 GeoGebr a and eX e Learning: applic abilit $\mathrm{y}$ in the teac hing of $\mathrm{P}$ hy s ic s and $\mathrm{M}$ athem at ic s SYSTEMICS, CYBERNETICS AND INFORMATICS 61-6

[18] Copriady J 2014 Penerapan SPBM yang diintegrasikan dengan Program eXe Learning Terhadap Motivasi Hasil Belajar Mahasiswa Pada Mata Kuliah Kimia Dasar Jurnal Pendidikan 95-105

[19] Azizaha S, Khuzaemahb E and Lesmanawatic I R 2017 Penggunaan Media Internet eXeLearning Berbasis Masalah pada Materi Perubahan Lingkungan untuk Meningkatkan Hasil Belajar Siswa SCIENTIAE EDUCATIA: JURNAL PENDIDIKAN SAINS 19 -213

[20] Sharples M 2000 The design of personal mobile technologies for lifelong learning Computers \& Education 177-93

[21] Baloch H Z, Abdulrhaman A and Ihad N A 2012 Mobile Collaborative Informal Learning Design: Study of Collaborative Effectiveness Using Activity Theory iJIM 34-41

[22] Kearney M, Schuck S, Burden K and Aubusson P 2012 Viewing mobile learning from a pedagogical perspective Research in Learning Technology 1-17

[23] Sarrab M and Elbasir M 2015 Instruction and Learning Design Consideration for the Development of Mobile Learning Application International Journal of Educational and Pedagogical Sciences 2922-25

[24] Marwan M E, Madar A R and Fuad N 2014 Development of Mobile EEF Learning System (MEEFLS) for Mobile Learning Implementation in Kolej Poly-Tech MARA (KPTM International Journal of Electrical and Computer Engineering 573-77

[25] Leung C H and Chan Y Y 2003 Mobile learning: A new paradigm in electronic learning In Proceedings of the 3rd IEEE international conference on advanced learning technologies, ed V Devedzic, J Spector, D Sampson, and Kinshuk (Athens, Greece: IEEE Computer Society Press) p 76-80

[26] Thiagarajan S, Semmel D and Semmel 1974 Instructional development (Bloomington: Indiana University)

[27] Sukarjo 2006 Kumpulan Materi Evaluasi Pembelajaran (Yogyakarta: Universitas Negeri Yogyakarta) 